Research Article

\title{
Innovation Efficiency of China's High-End Manufacturing Industry: Evidence from Super-SBM Model and Malmquist Index
}

\author{
Qiaochu Li $(\mathbb{D}$ and TingLi Liu $\mathbb{C}$ \\ College of Economics and Management, Beijing University of Technology, Beijing 100124, China \\ Correspondence should be addressed to Qiaochu Li; yuzaiye@126.com and TingLi Liu; 498230219@qq.com
}

Received 9 August 2019; Revised 7 November 2019; Accepted 13 November 2019; Published 5 December 2019

Academic Editor: Qiuye Sun

Copyright (c) 2019 Qiaochu Li and TingLi Liu. This is an open access article distributed under the Creative Commons Attribution License, which permits unrestricted use, distribution, and reproduction in any medium, provided the original work is properly cited.

\begin{abstract}
Technological innovation is an important engine to support the development of China from a big manufacturing country to a powerful manufacturing country. With the support of government policies, China's high-end manufacturing industry urgently needs to solve the problems of insufficient technological innovation and weak core competitiveness. This paper uses the superSBM model to measure the impact of incentive policies related to high-end manufacturing industry on innovation efficiency of China's high-end manufacturing industry in 2012-2017. The DEA Malmquist model is used to analyse the dynamic change trend of efficiency. The results show that the innovation efficiency of China's high-end manufacturing industry shows a trend of gradual optimization, stepping into the middle and high-end levels, but there are large differences in innovation efficiency among industries, and the optimization process is not stable; at the same time, China's high-end industry is not stable. Manufacturing industry needs to improve its pure technical efficiency as soon as possible and solve the problems of low efficiency of system and management level. Accordingly, this paper puts forward a series of policy suggestions, such as increasing financial and talent support, encouraging technological innovation, and promoting industrial synergy.
\end{abstract}

\section{Introduction}

Since 2010, China has issued a series of relevant industrial policies to support the transformation and development of manufacturing industry, putting forward the idea of "promoting traditional industries to move towards the middle and high-end," emphasizing the development of "high-end manufacturing areas," and enhancing technological innovation capabilities. General Secretary Xi Jinping has made important expositions on the transformation and upgrading of manufacturing industry on many occasions. Intelligent manufacturing should be the main direction to promote industrial technological change and optimization and upgrading, to promote the fundamental transformation of the manufacturing industry model and enterprise form, to promote the "reform the past" by "innovation," and to increase the stock, promoting China's manufacturing industry to the middle and high-end levels of global value chain. Premier Li Keqiang calls for adherence to the basic principles of "innovation-driven, quality first, green development, structural optimization, and talent-based." Therefore, improving the independent innovation capability (refers to the process of realizing the value of new products through the unique core technology of independent intellectual property rights and on this basis) of high-end manufacturing industry is an important driving factor for China to become a manufacturing power.

In November 2016, the State Council of China put forward "the National Strategic Emerging Industries Development Plan for the 13th Five-Year Plan," which clearly focuses on the new generation of information technology industry, high-end CNC machine tools and robots, aerospace equipment, marine engineering equipment and hightech ships, advanced rail transit equipment, energy saving and new energy vehicles, electric power equipment, agricultural machinery equipment, new materials, and biomedicine and high-performance medical devices. The above ten strategic emerging industries belong to high-end 
manufacturing industry. Compared with the traditional manufacturing industry, high-end manufacturing industry has relatively high technology level and production efficiency, relatively low labour intensity, and belongs to capitalintensive or technology-intensive industries. Innovation is the hardcore of high-end manufacturing industry. However, China's high-end manufacturing industry has poor innovation ability. Therefore, improving the innovation efficiency of China's high-end manufacturing industry is of great significance for China to transform into a powerful manufacturing country and enhance the comprehensive strength and international competitiveness of China's highend manufacturing industry.

In recent years, with the support of government policies, China's high-end manufacturing enterprises have continuously strengthened technological innovation and technological transformation, and the overall technological level of the industry has continued to improve. However, with the rapid development of the industry, many key components and supporting products lag behind. The core competitiveness of the high-end equipment manufacturing industry of independent brands has great room to improve. The lowend and middle-end production capacity is excessive, and the competition is fierce. The high-end links are controlled by foreign brands and are subject to imports, so the innovation ability is difficult to reach the expected level. Faced with the above problems, China needs to further improve the ecological environment of industrial innovation and put innovation at the core of the overall development. Therefore, this paper focuses on the research of innovation efficiency of high-end manufacturing industry under industrial incentive policy, aiming to solve the following problems: (1) the impact mechanism of innovation efficiency of China's highend manufacturing industry under industrial incentive policy and (2) the dynamic development trend of innovation efficiency of high-end manufacturing industry. The main research contributions of this paper are to provide optimization strategy and policy recommendations of innovation efficiency of high-end manufacturing industry.

\section{Literature Review}

2.1. Research on Industrial Upgrading of Manufacturing Industry under Industrial Policy. With the emergence of relevant policies to support the development of high-end manufacturing industry, improving the competitiveness of China's high-end manufacturing industry has gradually become the focus of policy research. Li pointed out that, in the process of the new industrial revolution, the key to building a strong manufacturing country lies in the development of advanced manufacturing industry, focusing on improving the pattern of China's advanced manufacturing industry, and accordingly put forward the adjustment and development path of advanced manufacturing industry [1]. Zhu et al. investigate the spatial features of technological innovation efficiency and examine the relationship between technology innovation efficiency and environmental regulations from a spatial perspective. The results indicate that China's provincial-level technological innovation efficiencies are uneven in space.
Voluntary regulation positively affects the technological innovation efficiency of industrial enterprises at the provincial level, while mandatory regulation has no significant impact [2]. Xin et al. summarized that the overall characteristics of China's manufacturing industry are big but not strong which is embodied in the following aspects.

(1) The main innovation ability is not strong enough, and the foundation is weak either. (2) The manufacturing industry is currently at the low end of the value chain. (3) Low efficiency of production and operation. (4) The industrial structure is unreasonable. (5) The product quality is poor. Besides, they established the concept of "Capital for Technology" [3]. Shao et al. put forward how to improve the competitiveness of manufacturing industry under the background of "re-industrialization" [4]. Yu and Zhang believe that the low-cost advantage of China's manufacturing industry is gradually weakening, the added value of products is low, and the ability of independent innovation is weak. In the future, China's manufacturing industry will realize the transformation from production factors to independent innovation and from product manufacturing to product creation and knowledge creation [5]. Based on this, the research in the field of industrial policy and manufacturing development focuses on the planning and construction of the overall development path and the choice of the development mode. Although there are some concerns and concerns about industrial innovation and upgrading, there is a lack of more in-depth and specific research in the field of innovation and development under the background of industrial policy.

\subsection{Research on Innovation Efficiency of High-End} Manufacturing Industry. At present, the academic research mainly involves the following three aspects.

In the aspect of innovation efficiency evaluation, Sun and Wang constructed the evaluation index system of industrial gross output value, total investment of scientific research funds, investment intensity of scientific research funds, and proportion of sales revenue of new products from three aspects: potential innovation ability, innovation input ability, and innovation output ability, and adopted the fuzzy synthesis method. The three-level evaluation method was used for data analysis [6]. Tian et al. found seven main factors that influenced business model innovation, namely, market pressure, government policy, entrepreneurship, culture and strategy, technology, human resources, and organizational capabilities, which indicate a possibility for Chinese high-end equipment manufacturers to improve their competitiveness and performance through better management of their business model innovation [7]. Huang et al. constructed a monitoring index system of innovation index of high-end manufacturing industry from a multilevel perspective [8]. Li et al. constructed the coupling model of technological innovation and knowledge integration. From the perspective of knowledge integration, they focused on designing three paths to enhance technological innovation capability based on supply chain, industrial alliance, and innovation platform [9]. Wang puts forward an evaluation method of industrial innovation and competitiveness suitable for the characteristics of high-end 
equipment manufacturing industry from five aspects: the main influencing factors of innovation, evaluation index, evaluation method, evaluation area, and evaluation industry [10]. Li et al. analysed the innovation efficiency of high-end manufacturing industry in the central region from a regional perspective, which was higher than that in the eastern and Western regions. The results showed that the innovation efficiency of the central and Western regions was the lowest [11]. Therefore, there are great differences in the evaluation methods of innovation efficiency among current scholars, and the dimensions and perspectives of the index system are also different.

In terms of the influencing factors of innovation efficiency, Yang and Cao Hui evaluated the internationalization level of technological innovation of universities in China from 2011 to 2015 through the superefficiency SBM model and found that R\&D personnel's technological innovation ability and internationalization vision need to be further improved. [12]. Park and Lee, who had analysed R\&D efficiency of 27 countries, found that there were differences in internationalization efficiency of technological innovation among different countries [13]. Libaers and Meyer pointed out that the level of industrial clusters is related to the internationalization of innovation companies [14]. Dai et al. explored this issue in an empirical study by using a two-stage chain data envelopment analysis (DEA) of TIE (technological innovation efficiency) followed by modifying the wages of TIT (technological innovation talents) and building a collaborative evolution model with spatial effects on a large dataset (from 2007 to 2016). The results show that the overall Chinese TIE is relatively low, and there are also divergences in the TIE at different stages in the regions we focus on [15]. Wang and Shi set up an index system of innovation measurement for HEM enterprises and analysed the common problems existing in HEM enterprises in China, such as the urgent need to optimize the organizational structure, the need for further rational planning of organizational resources allocation, and the lack of professional talent resources [16]. Du et al. established the WSR-AHP analysis method to construct the index system of innovation driving factors of small- and medium-sized technological enterprises from three aspects of innovation, management innovation, and personnel innovation. Through cluster analysis, the scientificalness and rationality of the index system were verified. It was found that the innovation spirit of entrepreneurs was the key to the development of enterprise innovation [17]. Du empirically analysed the promotion effect of producer services on manufacturing upgrading and its influencing factors from the perspective of industrial correlation efficiency. To sum up, the excavation of influencing factors of innovation efficiency mainly aims at the macrolevel, and the excavation of influencing mechanism related to industrial mechanism and policy is less, which needs to be further studied and solved [18].

Many scholars have studied the incentive policies related to high-end manufacturing industry and the impact of transformation and upgrading of China's manufacturing industry, the evaluation of innovation efficiency, and the analysis of influencing factors. In terms of development planning and mode of development, the transformation and upgrading path of manufacturing industry to enhance innovation ability and competitiveness is put forward. The evaluation of innovation efficiency is carried out from multidimensional and multiperspective, and the impact mechanism of innovation efficiency is explored at the macrolevel. Few of these studies take high-end manufacturing industry as the research object, and the results of exploring the impact of industrial policies on innovation efficiency need to be further studied. However, the views and methods put forward by these research results lay a foundation for further research in this paper. This paper studies the innovation efficiency of the high-end manufacturing industry, discusses the impact of China's policies to encourage the development of high-end manufacturing industry on the innovation efficiency of highend manufacturing industry, and puts forward reasonable suggestions for improving the innovation efficiency of highend manufacturing enterprises.

\section{Materials and Methods}

3.1. Innovation Efficiency Model Based on Super-SBM. In 2001, Tone first proposed the SBM model by setting slack variables in the objective function to facilitate the solution in a larger feasible region [19]. In 2002, Tone further improved the model and established a new super-SBM model [20]. The model can not only measure the efficiency of different samples but also compare the efficiency of effective samples by allowing the efficiency of effective samples to be greater than 1 . This paper chooses super-SBM model to measure and analyse the innovation efficiency of high-end manufacturing industry. The general form of the model is

$$
\left\{\begin{array}{l}
\min \quad \rho=k-\frac{1}{m} \sum_{i=1}^{m} \frac{S_{i}^{-}}{x_{i 0}}, \\
\text { s.t. } \quad 1=k+\frac{1}{S} \sum_{r=1}^{S} \frac{S_{i}^{+}}{y_{r 0}} \\
k x_{i 0}=\sum_{j=1 ; j \neq 0}^{n} \lambda_{j} x_{i j}+s_{i}^{-}, \\
k y_{r 0}=\sum_{j=1 ; j \neq 0}^{n} \lambda_{j} y_{r j} j+s_{r}^{+}, \\
A_{j} \geq 0, s_{i}^{-} \geq 0, s_{r}^{+} \geq 0, t>0,
\end{array}\right.
$$

where we first assume that $n$ high-end manufacturing industries are selected as evaluation samples and then define $X=x_{i j}$ and $Y=y_{i j}$ as vectors of innovation input and innovation output elements of the above industries, $\rho$ represents innovation efficiency value of high-end manufacturing industries, and $m$ and $k$ represent types of input and output indicators, respectively. Then $x_{\mathrm{i} 0}(i=1, \ldots, m)$ and $y_{r 0}(r=1$, $\ldots, k)$ can be expressed as elements of $X$ and $Y$, as column vectors, and $s_{i}^{-}$and $s_{r}^{+}$as relaxation variables of input and 
output of innovation efficiency. Finally, the model can effectively measure the innovation efficiency of high-end manufacturing industry.

\subsection{Malmquist Innovation Efficiency Index Model. When} analysing panel data with multiple time observations, production technology usually changes in the actual process. The Malmquist index method can reflect the comprehensive efficiency, technical efficiency, and total factor productivity of samples in multiple periods and can dynamically reflect the sample data in different time series. The change of the efficiency value is helpful to find out the factors affecting the change of efficiency. The Malmquist index was first put forward by S. Malmquist in 1953, aiming at the change of consumption bundle in the consumption function in the indifference curve. Later, Caves and others put forward the formal concept of the Malmquist exponent by calculating the ratio of distance function, and then the results of Cave were validated in the study of Fare and others, which generalized the Malmquist exponent method [21]. In the current DEA model, Fare and others' model is widely used, which can be expressed as follows:

$$
M\left(y_{t+1}, x_{t+1}, y_{t}, x_{t}\right)=\left\lceil\frac{D^{t}\left(x_{t+1}, y_{t+1}\right)}{D^{t}\left(x_{t}, y_{t}\right)} \times \frac{D^{t+1}\left(x_{t+1}, y_{t+1}\right)}{D^{t+1}\left(x_{t} y_{t}\right)}\right\rceil^{(1 / 2)},
$$

where $\mathrm{D}^{t}\left(x_{t}, y_{t}\right)$ and $\mathrm{D}^{t}\left(x_{t+1}, y_{t+1}\right)$ represent the validity of DMU in $t$ and $t+1$ time periods, respectively, while $\mathrm{D}^{t+1}\left(x_{t}, y_{t}\right)$ represents the validity of DMU in $t+1$ time period. If the evaluation index IM $>1$ indicates that productivity has increased compared with the previous period, it means that the productivity level has increased; if the evaluation index IM = 1 indicates that productivity is the same as that of the previous period, it means that the productivity level has not changed; if the evaluation index $\mathrm{IM}<1$, it means that the productivity level is lower than that of the previous period, it means that productivity level is lower. At the same time, researchers found that the index can be further decomposed:

$$
\begin{aligned}
M\left(y_{t+1}, x_{t+1}, y_{t}, x_{t}\right)= & \frac{D^{t+1}\left(x_{t+1}, y_{t+1}\right)}{D^{t}\left(x_{t} y_{t}\right)}\left\lceil\frac{D^{t}\left(x_{t+1}, y_{t+1}\right)}{D^{t+1}\left(x_{t+1}, y_{t+1}\right)}\right. \\
& \left.\times \frac{D^{t}\left(x_{t}, y_{t}\right)}{D^{t+1}\left(x_{t}, y_{t}\right)}\right\rceil^{(1 / 2)} .
\end{aligned}
$$

Namely, comprehensive efficiency can be decomposed into the product of the technical efficiency index (EC) and technical progress index (TC), and EC can be further decomposed into the product of the scale efficiency value (SC) and pure technical efficiency value (PC). EC represents the change of efficiency in two adjacent evaluation periods. If EC $>1$ indicates that the organizational units are approaching the production frontier, there is obvious progress. TC reflects the technological progress. If TC $>1$, it shows that the organizational unit leads to the frontier-oriented change of production frontier through technological progress.

3.3. China's Policies on High-End Manufacturing. Since 2010, China has promulgated and implemented a series of policies related to accelerating the cultivation and development of strategic emerging industries. The intensity of the policies has continued to increase, and some of the policies implemented have made progress. This paper chooses the relevant policies to promote the innovation and development of high-end manufacturing industry as shown by the Industrial 4.0 Research Institute and the Chinese government website from 2011 to 2017. Relevant policies play an important role in stimulating the innovative development of high-end manufacturing industry. In the period of policy dividends and strategic opportunities, the innovative development of high-end manufacturing industry may be affected in the following aspects:

(1) Technology research and development and investment: first, at the technical level, the state promotes institutional and institutional innovation, strengthens organizational leadership, deepens international cooperation, and improves the level of international development. The key support of relevant policies helps integrate high-quality technology-based enterprises in the field of high-end equipment manufacturing in the international scope, thus forming an ecology of high-end equipment technology cluster covering scientific and technological research and development, scientific and technological transformation, product development and product production, and promoting complementary cooperation among enterprises at the level of advanced technology. On this basis, the innovative situation of national support, industry association leader, and enterprise joint breakthrough is finally formed, and the technological advantages are strengthened, which is expected to achieve the effective improvement of the overall innovation efficiency of the industry.

(2) Financial support and market cultivation: from the perspective of capital, the state should strengthen financial policy support, guide and encourage social investment and actively cultivate the market, and create a good market environment, which will help ease the financial pressure of high-end manufacturing industry. The development of highend manufacturing industry cannot be separated from the support of funds. By means of financial input, tax preferences, and financial support, the transaction and financing costs of enterprises will be greatly reduced, the role of financial institutions as a bridge for the transfer of funds will be brought into full play, and the circulation of funds between virtual and real economies will be accelerated. Policy support to effectively supplement capital investment and 
standardize the market environment will help highend manufacturing industry to have a more perfect innovation environment and then achieve innovation and optimization development.

(3) Talent training strategy: the development of highend manufacturing industry relies heavily on middle and high-end talents.

Based on the policy environment and favourable background, strengthening the talent support for high-end manufacturing industry and creating $\mathrm{R} \& \mathrm{D}$ innovation platform for high-end equipment manufacturing industry will help solve the problems of insufficient R\&D and innovation in the development of high-end manufacturing industry. Developing core technology and breaking through international technical barriers will accelerate the technological transformation of high-end manufacturing industries and support industrial innovation and development. The relevant policies of high-end manufacturing industry from 2011 to 2018 are shown in Table 1.

3.4. Evaluation Index System of Innovation Driving Factors in High-End Manufacturing Industry. In high-end manufacturing enterprises, human resource factors have a significant impact on the innovation of enterprises, capital factors are the effective support for high-end manufacturing enterprises to achieve independent innovation, and technological innovation is the key to sustainable development of high-end manufacturing industry. Referring to China Enterprise Innovation Ability Evaluation Report 2016 issued by China Institute of Science and Technology Development Strategy in 2016 and combining the characteristics of high-end manufacturing industry, a set of relatively reasonable evaluation index system of innovation driving factors of high-end manufacturing industry is established, including five first-level indicators and eight second-level indicators, and among them innovation input index mainly reflects the role and relationship of the main bodies in the national innovation system; innovation output index mainly reflects the intermediate output of innovation, and the specific variable description is shown in Table 2.

Among them, the total internal expenditure of $R \& D$ funds refers to the actual expenditure of enterprises for scientific and technological activities, including labour, scientific research business, scientific research management fees, fixed assets purchased and constructed by noninfrastructure investment, scientific research infrastructure expenditure, and other expenditures for scientific and technological activities. Expenditure on technology importation and technological transformation refers to the work of mastering, applying and replicating the imported technology, and the necessary equipment fees and duplication fees on this basis.

\section{Results}

4.1. Data. In this paper, 22 small and medium-sized manufacturing industries of five high-end manufacturing
TABLE 1: High-end manufacturing policies.

\begin{tabular}{|c|c|}
\hline Release time & Policy name \\
\hline 2011.12 & $\begin{array}{c}\text { Planning for Industrial Transformation and } \\
\text { Upgrading (2011-2015) }\end{array}$ \\
\hline 2012.5 & $\begin{array}{l}\text { Development Plan of High-End Equipment } \\
\text { Manufacturing Industry in the 12th Five-Year Plan }\end{array}$ \\
\hline 2012.7 & $\begin{array}{l}\text { National Strategic Emerging Industries } \\
\text { Development Plan for the Twelfth Five-Year Plan }\end{array}$ \\
\hline 2013.5 & $\begin{array}{l}\text { Medium and Long Term Development Plan for } \\
\text { Civil Aviation Industry }(2013-2020)\end{array}$ \\
\hline 2013.5 & $\begin{array}{c}\text { Guidelines for Scientific Research Projects of } \\
\text { Marine Engineering Equipment }\end{array}$ \\
\hline 2013.12 & $\begin{array}{c}\text { Guidance on Promoting the Development of } \\
\text { Industrial Robot Industry }\end{array}$ \\
\hline 2014.3 & $\begin{array}{c}\text { Encouraging import technology and product } \\
\text { catalogue }\end{array}$ \\
\hline 2014.3 & $\begin{array}{l}\text { Some Opinions on the Popularization and } \\
\text { Application of Beidou Satellite Navigation System }\end{array}$ \\
\hline 2015.5 & Made-in-China 2025 \\
\hline 2016.1 & $\begin{array}{l}\text { Outline of Quality Management Planning for } \\
\text { Machinery Industry in the 13th Five-Year Plan }\end{array}$ \\
\hline 2016.3 & Robot Industry Development Plan (2016-2020) \\
\hline 2016.5 & $\begin{array}{l}\text { Guidance on Deepening the Integration of } \\
\text { Manufacturing Industry and Internet }\end{array}$ \\
\hline 2016.8 & $\begin{array}{l}\text { Standardization and Quality Improvement } \\
\text { Planning of Equipment Manufacturing Industry }\end{array}$ \\
\hline 2016.11 & $\begin{array}{l}\text { National Strategic Emerging Industries } \\
\text { Development Plan for the 13th Five-Year Plan }\end{array}$ \\
\hline 2016.12 & $\begin{array}{l}\text { Intelligent Manufacturing Development Plan } \\
(2016-2020)\end{array}$ \\
\hline 2017.1 & $\begin{array}{c}\text { Action Plan for Deepening Structural Adjustment } \\
\text { and Accelerating Upgrading of Shipbuilding } \\
\text { Industry (2016-2020) }\end{array}$ \\
\hline 2017.7 & $\begin{array}{c}\text { Development Planning of New Generation } \\
\text { Artificial Intelligence }\end{array}$ \\
\hline 2017.8 & $\begin{array}{c}\text { Civil Aviation Administration's Guiding Opinions } \\
\text { on Promoting Domestic Civil Aviation Industry } \\
\text { Going Out }\end{array}$ \\
\hline 2017.11 & $\begin{array}{l}\text { High-End Intelligent Remanufacturing Action Plan } \\
\qquad(2018-2020)\end{array}$ \\
\hline 2017.11 & $\begin{array}{c}\text { Action Plan for Sustainable and Healthy } \\
\text { Development of Marine Engineering Equipment } \\
\text { Manufacturing Industry }\end{array}$ \\
\hline 2018.1 & $\begin{array}{l}\text { White Paper on Artificial Intelligence } \\
\text { Standardization (2018 Edition) }\end{array}$ \\
\hline
\end{tabular}

industries in China are taken as research objects (among which the robot manufacturing industry data are incomplete and excluded), and the innovation efficiency of each subindustry in the high-end manufacturing industry was evaluated and analysed. The research time range is from 2012 to 2017. The data are from China Science and Technology Statistical Yearbook. The specific industries are shown in Table 3.

4.2. Efficiency Analysis. In this paper, 22 small- and medium-sized industries in high-end manufacturing industry from 2012 to 2017 are taken as decision-making units, and the industrial data are dimensionless. Then input DEA solver 5.0 software, use the super-SBM model to calculate the 
TABLE 2: Variable description.

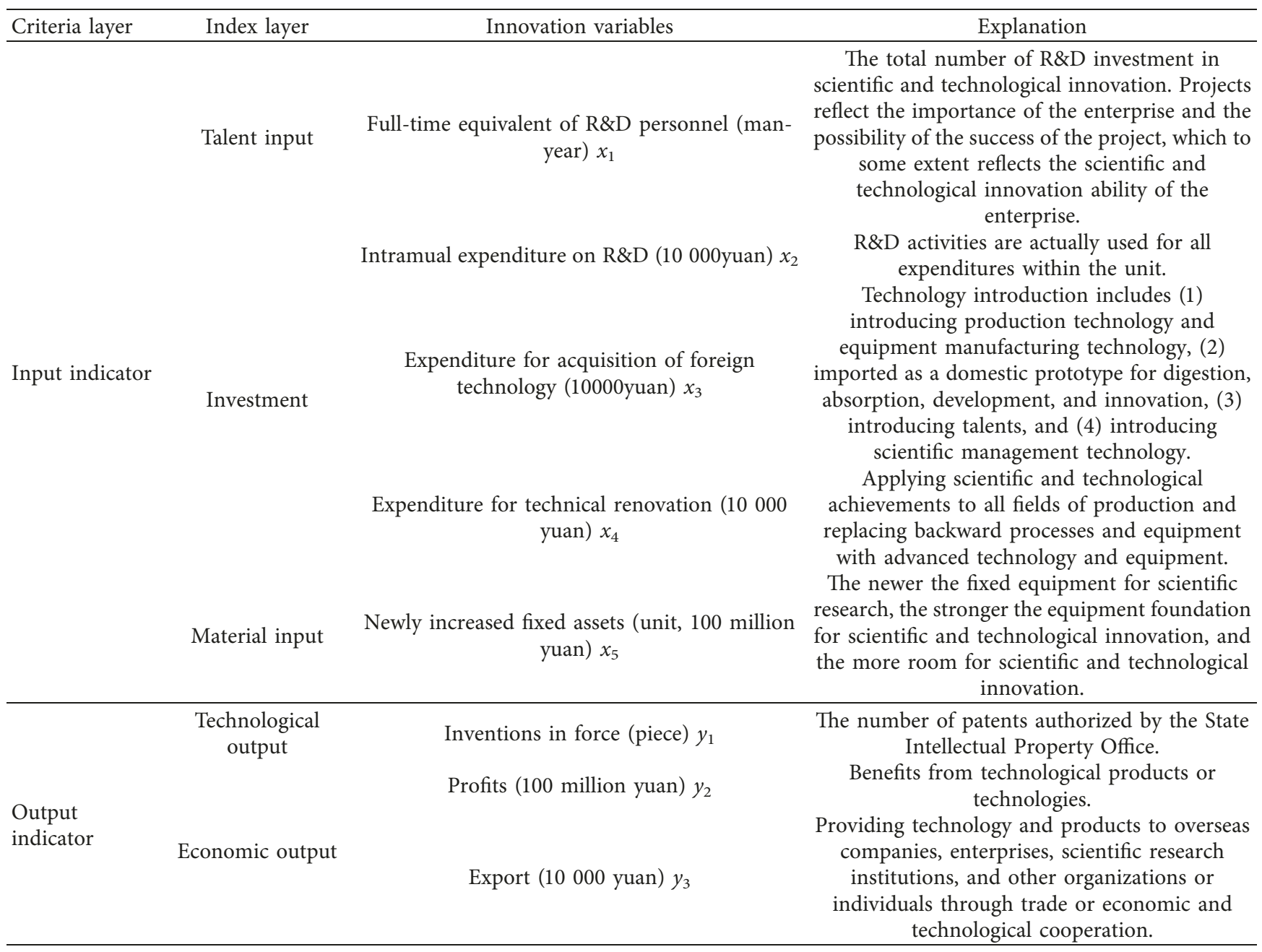

efficiency value, and evaluate and compare the efficiency level of industrial innovation in three years before and after the promulgation of the policy. The average efficiency of each industry is shown in Table 4.

4.3. Malmquist. The Malmquist index is a powerful tool to analyse the changing trend of total factor technological innovation efficiency in various industries. The total factor productivity index (Tfpch) can be further decomposed into technological progress index (Techch), technical efficiency index (Effch), pure technical efficiency index (Pech), and scale efficiency index (Sech). According to Malmquist index theory, if the change of efficiency is greater than 1 , the innovation level of China's high-end manufacturing industry has improved. The technology progress index is mainly related to full-time equivalent of R\&D personnel, intramural expenditure on $\mathrm{R} \& \mathrm{D}$, expenditure for acquisition of foreign technology, expenditure for technical renovation, and newly increased fixed assets, and other conditions are relevant.

In order to make a further dynamic analysis of innovation efficiency of China's high-end manufacturing industry, this paper uses DEAP2.1 software to calculate and decompose the
Malmquist productivity index from 22 panel data of China's high-end manufacturing industry from 2012 to 2017. The results of annual productivity index calculation are shown in Table 5. The calculation results of high-end manufacturing industry productivity index are shown in Table 6.

\section{Discussion}

\subsection{Innovation Efficiency Analysis of China's High-End Manufacturing Industry}

5.1.1. Industrial Perspective. From 2012 to 2017, there are 8, $7,8,9,11$, and 8 industries with effective innovation, respectively. This shows that the innovation efficiency of China's high-end manufacturing industry has an upward trend under the guidance of policy. China's manufacturing industry is changing from relying on imitating foreign achievements and using a large number of low-level labour force to the growth mode driven by technological innovation, and gradually becoming smaller. In the case of the low-level labour force scale, the connotative growth mode of economic growth depends on its own technological innovation factors and technological factors. However, as the transition from China's economy to high-quality 
TABLE 3: Classification of China's high-end manufacturing industry.

\begin{tabular}{lc}
\hline Large industry & Small- and medium-sized industries \\
\hline Manufacture of medicines & $\begin{array}{c}\text { Manufacture of chemical medicine } \\
\text { Manufacture of finished traditional Chinese herbal } \\
\text { medicine }\end{array}$ \\
\hline Manufacture of aircraft and spacecraft & Manufacture of biological medicine \\
\hline
\end{tabular}

Manufacture of communication equipment Manufacture of communication system equipment Manufacture of communication terminal equipment Manufacture of broadcasting and TV equipment Manufacture of radar and its fittings

Manufacture of electronic equipment and communication equipment

Manufacture of audio and video equipment Manufacture of electronic appliances

Manufacture of electronic vacuum appliances Manufacture of semiconductor discreting appliances Manufacture of integrate circuit

Manufacture of electronic components Manufacture of other electronic equipment Manufacture of entire computer

Manufacture of computers and office equipment Manufacture of parts and fixture for computer Manufacture of computer peripheral equipment

Manufacture of medical equipment and measuring instrument and meter

Manufacture of medical equipment and appliances Manufacture of measuring instrument and meter

TABLE 4: Innovation efficiency of some high-end manufacturing industries in China from 2012 to 2017.

\begin{tabular}{lcccccccc}
\hline Manufacturing classification & 2012 & 2013 & 2014 & 2015 & 2016 & 2017 & Mean & Rank \\
\hline Chemical medicine & 0.070 & 0.065 & 0.039 & 0.088 & 0.157 & 0.039 & 0.076 & 20 \\
Finished traditional Chinese herbal medicine & 1.141 & 1.098 & 1.153 & 1.141 & 1.136 & 0.027 & 0.950 & 6 \\
Biological medicine & 1.008 & 0.074 & 0.052 & 1.118 & 0.182 & 0.056 & 0.415 & 10 \\
Airplanes & 0.028 & 0.037 & 0.039 & 0.019 & 0.065 & 1.570 & 0.293 & 12 \\
Spacecraft & 0.001 & 0.001 & 0.002 & 0.001 & 0.005 & 1.467 & 0.246 & 13 \\
Communication equipment & 1.000 & 1.000 & 1.000 & 1.000 & 1.000 & 1.000 & 1.000 \\
Communication system equipment & 1.282 & 1.507 & 1.385 & 1.688 & 1.996 & 2.721 & 1.763 \\
Communication terminal equipment & 1.120 & 1.169 & 1.028 & 1.221 & 1.157 & 1.144 & 1.140 \\
Broadcasting and TV equipment & 0.147 & 0.213 & 0.086 & 0.136 & 0.284 & 0.034 & 0.150 \\
Radar and its fittings & 0.025 & 0.026 & 0.019 & 0.022 & 0.084 & 0.046 & 0.037 \\
Audio and video equipment & 1.020 & 0.349 & 0.295 & 0.313 & 1.009 & 0.043 & 0.505 \\
Electronic appliances & 0.171 & 0.198 & 0.209 & 0.318 & 0.361 & 0.046 & 0.217 \\
Electronic vacuum appliances & 0.121 & 1.324 & 1.452 & 1.009 & 1.010 & 0.112 & 0.838 \\
Semiconductor discreting appliances & 0.044 & 0.116 & 0.074 & 0.110 & 0.206 & 0.025 & 0.096 \\
Integrate circuit & 0.164 & 0.203 & 0.193 & 0.252 & 0.315 & 0.063 & 0.198 \\
Electronic components & 0.145 & 0.163 & 0.151 & 0.281 & 0.407 & 0.030 & 0.196 \\
Other electronic equipment & 0.058 & 0.087 & 0.221 & 0.400 & 1.002 & 0.153 & 0.320 \\
Entire computer & 2.774 & 1.406 & 1.570 & 1.794 & 1.990 & 1.280 & 1.802 \\
Parts and fixture for computer & 1.471 & 1.321 & 1.380 & 1.056 & 1.493 & 0.119 & 1.140 \\
Computer peripheral equipment & 0.247 & 0.455 & 1.037 & 1.302 & 1.003 & 1.021 & 0.844 \\
Medical equipment and appliances & 0.067 & 0.059 & 0.086 & 0.089 & 1.001 & 0.031 & 0.222 & 1 \\
Measuring instrument and meter & 0.044 & 0.048 & 0.046 & 0.090 & 0.147 & 0.036 & 0.068 \\
Mean & 0.552 & 0.496 & 0.524 & 0.611 & 0.728 & 0.503 & 21 \\
\hline & & & & & & 14 \\
\hline
\end{tabular}

development is still in its infancy, manufacturing industry has not yet got rid of scale-driven path dependence. The transformation from quantity expansion to quality improvement will be a long process, and there may also be fluctuations. This is related to the development stage of China's equipment manufacturing and the previous industrial policy focus to scale expansion.
From Figure 1, we can see that there is a huge gap in innovation efficiency among different industries of high-end manufacturing industry, and the development of some industries is not optimistic. Only the innovations of manufacture of parts and fixture for computer (1.140), manufacture of an entire computer (1.802), manufacture of communication terminal equipment (1.140), manufacture of 
TABLE 5: Malmquist index and decomposition of innovation efficiency of China's high-end manufacturing industry in $2012-2017$.

\begin{tabular}{|c|c|c|c|c|c|}
\hline Manufacturing classification & Effch & Techch & Pech & Sech & Tfpch \\
\hline Chemical medicine & 0.826 & 1.291 & 0.797 & 1.037 & 1.066 \\
\hline Finished traditional Chinese herbal medicine & 0.881 & 1.201 & 0.891 & 0.989 & 1.058 \\
\hline Biological medicine & 0.808 & 1.322 & 0.823 & 0.982 & 1.068 \\
\hline Airplanes & 1.210 & 4.382 & 1.027 & 1.178 & 5.301 \\
\hline Spacecraft & 1.418 & 2.993 & 1.000 & 1.418 & 4.245 \\
\hline Communication equipment & 1.000 & 1.042 & 1.000 & 1.000 & 1.042 \\
\hline Communication system equipment & 1.000 & 1.435 & 1.000 & 1.000 & 1.435 \\
\hline Communication terminal equipment & 1.000 & 0.893 & 1.000 & 1.000 & 0.893 \\
\hline Broadcasting and TV equipment & 1.028 & 1.032 & 0.978 & 1.051 & 1.062 \\
\hline Radar and its fittings & 1.069 & 1.062 & 1.000 & 1.069 & 1.136 \\
\hline Audio and video equipment & 0.894 & 1.067 & 0.900 & 0.993 & 0.953 \\
\hline Electronic appliances & 1.076 & 1.069 & 0.937 & 1.147 & 1.150 \\
\hline Electronic vacuum appliances & 0.986 & 1.119 & 1.000 & 0.986 & 1.103 \\
\hline Semiconductor discreting appliances & 1.043 & 1.104 & 0.964 & 1.082 & 1.152 \\
\hline Integrate circuit & 1.068 & 1.203 & 1.038 & 1.028 & 1.283 \\
\hline Electronic components & 1.004 & 1.059 & 0.902 & 1.113 & 1.063 \\
\hline Other electronic equipment & 0.918 & 1.185 & 0.914 & 1.004 & 1.089 \\
\hline Entire computer & 1.000 & 0.855 & 1.000 & 1.000 & 0.855 \\
\hline Parts and fixture for computer & 0.937 & 0.813 & 0.952 & 0.985 & 0.762 \\
\hline Computer peripheral equipment & 1.062 & 1.061 & 1.000 & 1.062 & 1.127 \\
\hline Medical equipment and appliances & 1.012 & 1.077 & 1.004 & 1.008 & 1.090 \\
\hline Mean & 1.011 & 1.346 & 0.958 & 1.054 & 1.425 \\
\hline
\end{tabular}

TABle 6: Tfpch and decomposition of innovation efficiency of China's high-end manufacturing industry in 2012-2017.

\begin{tabular}{lccccc}
\hline Year & Effch & Techch & Pech & Sech & Tfpch \\
\hline 2013 & 1.053 & 0.995 & 0.93 & 1.133 & 1.048 \\
2014 & 1.111 & 1.158 & 1.022 & 1.088 & 1.286 \\
2015 & 0.952 & 0.972 & 0.949 & 1.003 & 0.925 \\
2016 & 1.181 & 0.984 & 1.125 & 1.062 & 1.162 \\
2017 & 0.878 & 1.907 & 0.873 & 1.004 & 1.675 \\
Mean & 1.035 & 1.203 & 0.980 & 1.058 & 1.219 \\
\hline
\end{tabular}

communication system equipment (1.763), and manufacture of communication equipment (1.000) are effective. About $22.73 \%$ of the total decision-making unit and $63.64 \%$ of the total decision-making unit are industries with innovation efficiency value less than 0.8 . It can be seen that the innovation achievements of high-end manufacturing industry are seriously polarized, especially the innovation efficiency value of manufacture of radar and its fittings is only 0.037 , which is much lower than the effective value of 1 , is 1.765 different from the manufacturing of entire computer (1.802), and has the highest innovation efficiency.

Among them, the main reason for the low innovation efficiency of manufacture of radar and its fittings is the lack of basic research and few relevant policy supports. Although China has also intensified its research efforts in recent years, the previous data accumulation is less and the research is not deep enough. At the same time, the relevant policy support is relatively small and the research funds are less, so most theories are only practiced in laboratory. The performance of radar in antijamming and human-computer interaction needs to find problems with users and improve iteratively after it is applied in actual or near-real combat. Only in this way can breakthroughs be made repeatedly. To provide users with first-class and easy-to-use equipment, by contrast, China has constantly introduced policies to support the development of AI, big data, information security, and other industries, and the emergence of emerging technologies has stimulated innovation enthusiasm of manufacturing of entire computer to a certain extent (for relevant policies, one can refer to Section 3.3). At the same time, China will increase government purchases through smart city construction, increasing investment in information technology, and enhancing e-government penetration, which will support the development of hardware and software industries to a certain extent. On this basis, with the accelerated development of the Internet and mobile Internet, technological innovation continues to promote industrial change. Internet giants and start-ups have laid out new models and new technologies to tap trillion-level markets. The development and application of new technologies represented by artificial intelligence will accelerate the transformation of traditional industries and further promote the prosperity and development of information and technology industries. It can be seen that the great difference in innovation efficiency is due to the high position of China's industrial policy, which has influenced the free development of the market and formed an imperfect competitive market, which has become an obstacle to the transformation of China's manufacturing industry to innovation-driven development. As for aerospace and other industries in the early stage of development, they are at the core of the industrial chain and the high-end of the value chain, with certain industry barriers, still in the lead-in period of industrial development, with high $\mathrm{R} \& \mathrm{D}$ investment requirements, and should be given more funds and R\&D support.

5.1.2. Time Angle. Figure 2 clearly reflects the changing trend of the annual average value of high-end manufacturing 


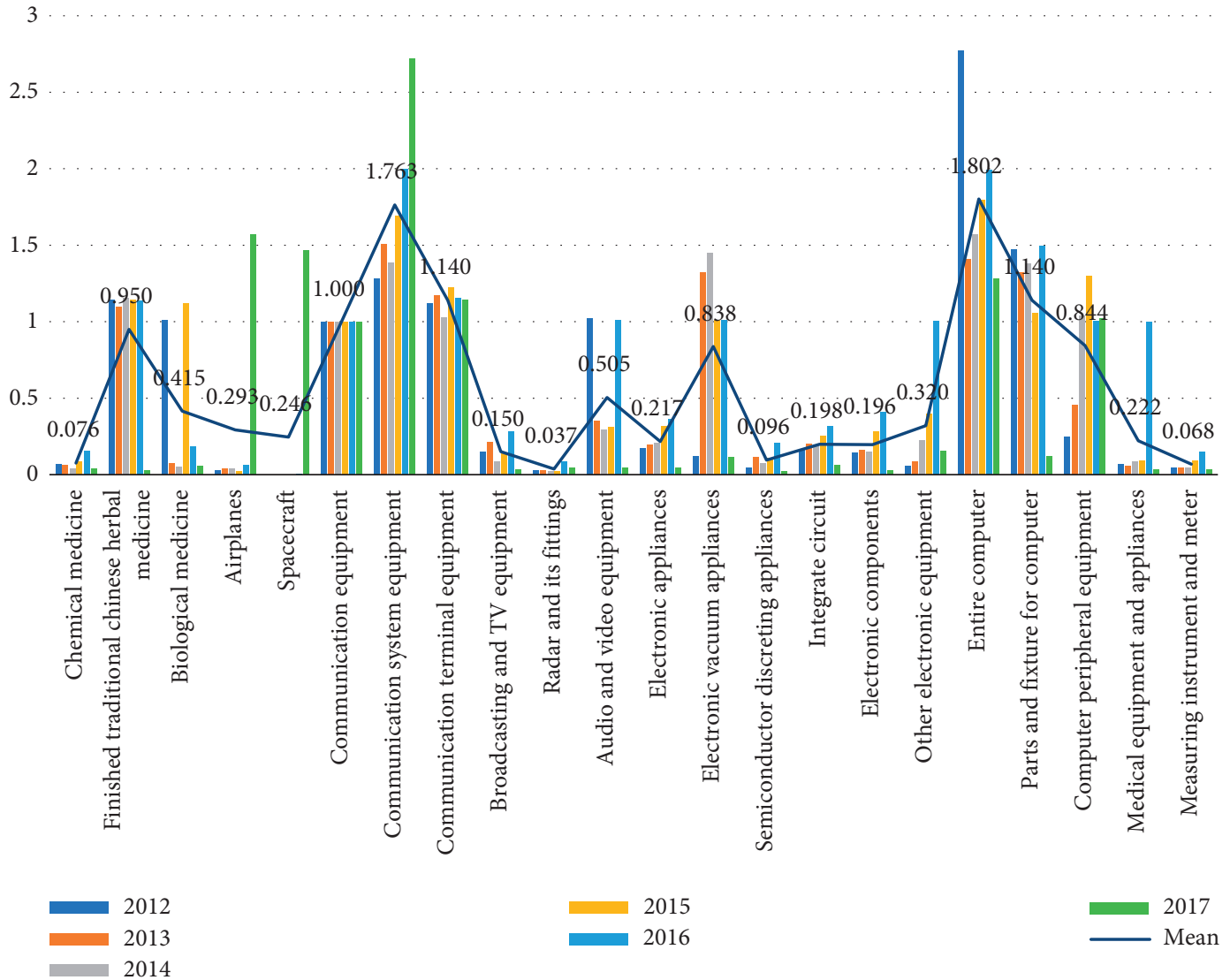

Figure 1: Mean innovation efficiency of some high-end manufacturing industries in China from 2012 to 2017.

industry in 2012-2017. The innovation efficiency of high-end manufacturing industry in China developed steadily from 2012 to 2015 . The average innovation efficiency varied greatly from year to year. In 2016, the innovation efficiency reached its peak (6.696), the second highest in 2015 (5.585), and the largest increase in 2015-2016 (0.111). It shows that, after the promulgation of Made-in-China 2025 policy, the transformation of China's manufacturing industry to highend manufacturing industry has been relatively successful in the past two years. However, from 2016 to 2017, it fell by $21.5 \%$. Referring to the relevant information released by China industrial information network, this paper believes that the reasons for the sharp decline in innovation efficiency in 2016-2017 are as follows: (1) The price of raw materials and the cost of human resources have increased significantly. With the rising cost of labour, production cost, and other factors of production in China, the growth rate of investment and export has slowed down significantly, and the extensive development mode dominated by resource investment and scale expansion is difficult to sustain. (2) China's economic growth rate has gradually slowed down. In addition, China's economy has been in the "L" type for a long time, and it is difficult to fundamentally change the coexistence of aggregate demand and overcapacity. From the trend of China's GDP and industrial added value, we can see that, in 2015 and 2016, China's quarterly GDP was basically stable at $6.7 \%-7.0 \%$ and the cumulative industrial added value was basically stable at $6.0 \%-7.0 \%$ year on year. (3) The collaborative development level of domestic high-end manufacturing enterprises is relatively low. With the increasing demand of domestic high-end manufacturing enterprises for collaborative production, the level of cloud computing technology that can meet the needs of collaborative production still needs to be improved. This technology has not been fully applied to the collaborative production process, increasing additional burden and support expenditure, and increasing innovation costs. (4) In addition, China's equipment manufacturing enterprises need to pay more attention to digestion and absorption of technology. In 2014, China's equipment manufacturing enterprises above designated size spent $73 \%, 4 \%, 5 \%$, and $18 \%$, respectively, on technology introduction, absorption, purchase of domestic technology, and technological transformation. Among them, the proportion of expenditure on digestion and absorption technology is the lowest, only $4 \%$. Most of China's equipment manufacturing industry is still in the catch-up stage. Learning to imitate the advanced technology of developed countries implies great late development advantages. However, China's equipment manufacturing enterprises are lack of digestion and absorption power because it is difficult to tackle key technologies and transform them into their own products in a short period of time, and the patent protection mechanism is not perfect. After spending a lot of time and energy to tackle difficulties, it is more likely to be plagiarized by other enterprises. 


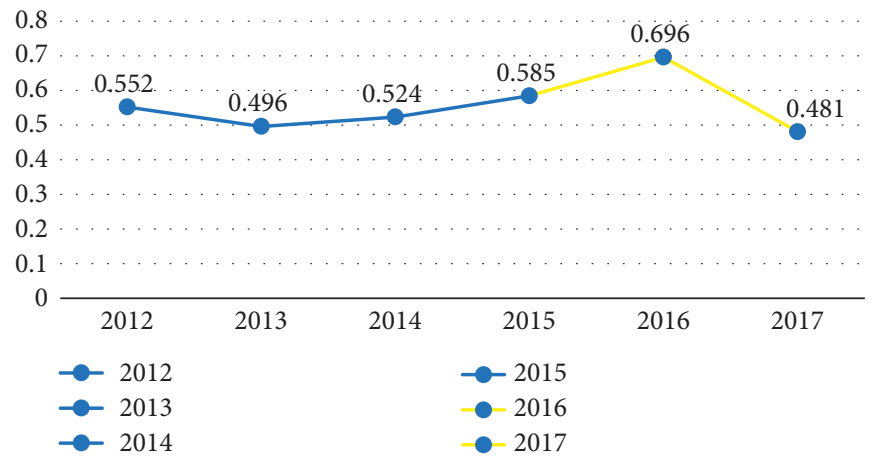

Figure 2: Comparison of annual average innovation efficiency of high-end manufacturing industry in 2012-2017.

\subsection{Analysis on the Further Decomposition of Innovation Efficiency of High-End Manufacturing Industry}

5.2.1. Industrial Perspective. From Table 5, we can see that pure technical efficiency index (Pech) is the main reason for the general decline of innovation in China's high-end manufacturing industry, which is due to the inefficiency of system and management level in China's high-end manufacturing enterprises, which seriously affects the production efficiency. The low technological efficiency limits the development of manufacture of communication terminal equipment and manufacture of entire computer in innovation, which indicates that the innovation ability and level of high-end manufacturing industry need to be further improved, and each industry should increase its technological innovation and investment. Pure technical efficiency index (Pech) and scale efficiency index (Sech) are the main factors that restrict the improvement of total factor productivity of manufacture of finished traditional chinese herbal medicine, manufacture of biological medicine, and manufacture of audio and video equipment, indicating that the factors of the management level have not been reasonably improved. And the contribution of technological innovation and technological progress to the change of input efficiency is weak and even inhibits the development of enterprises in the field of innovation. Manufacture of parts and fixture for computer is at a disadvantage in terms of technological progress index (Techch), pure technical efficiency index (Pech), and scale efficiency index (Sech). The development of innovation, technological innovation and investment in technology, and management level needs to be improved, and the scale of industry is not close to the optimal scale.

Due to the current development of equipment manufacturing industry in all regions, a series of preferential policies are generally given, resulting in repeated construction of some equipment manufacturing, which may lead to overcapacity and disordered competition. After the introduction of relevant industrial development plans, megacities and remote towns have begun to build relevant projects and similar industrial parks, which is likely to lead to problems such as repeated construction and overcapacity. There are also some projects that rely heavily on national and local development strategies. Once domestic demand is saturated or development plans are adjusted, equipment manufacturing enterprises will face major problems of product adjustment. For example, in 2011, due to the impact of Fukushima nuclear accident in Japan, the national nuclear power project was stopped, and the manufacturing capacity of nuclear power equipment was largely drained and the benefit declined; in recent years, driven by environmental protection and other strategies, the national newly approved thermal power project was reduced, the demand for thermal power equipment was greatly reduced, and the capacity was in large excess; once the market of domestic rail transit construction is saturated in the future, the market will pay more attention to rail transit The demand for communication-related equipment will also be greatly reduced.

Figure 3 shows intuitively the technical efficiency index (Techch), pure technical efficiency index (Pech) and scale efficiency index (Sech) of different industries in China's high-end manufacturing industry from 2012 to 2017. Manufacturing of airplanes (4.38) and manufacturing of spacecraft (3.00) are effective and far higher than other industries; that is, aerospace enterprises are approaching the optimal scale, which is due to the 13th Five-Year Plan. It is planned that the aerospace industry will be listed as a key industry for support and development, and during the 13th Five-Year Plan period, the degree of opening up of the aerospace industry will be further increased, and restrictions on all aspects of the country will be further liberalized. In the second half of 2015, China fully liberalized low-altitude flights in the field of general aviation, ushering in absolute rapid development. According to the Advisory Committee on Strategies for Building Made-in-China Powerful Countries, in line with the Made-in-China 2025 Strategy, China's aeroengine industry will exceed 70 billion yuan by the end of the 13th Five-Year Plan, and some products will enter the international market; by 2025, the industry will exceed 100 billion yuan, and the industry is expected to enter the world's first echelon. At the same time, core industrial areas (Shenyang, Xi'an, Chengdu, Harbin, and Nanchang) are also accelerating the building of regional integration of the aviation industry cluster. Taking East China as an example, many cities in the Yangtze River Delta, such as Shanghai, Zhenjiang, Changzhou, and Jiaxing, have formulated plans for the development of aviation industry based on supporting production of C919 aircraft and have established 


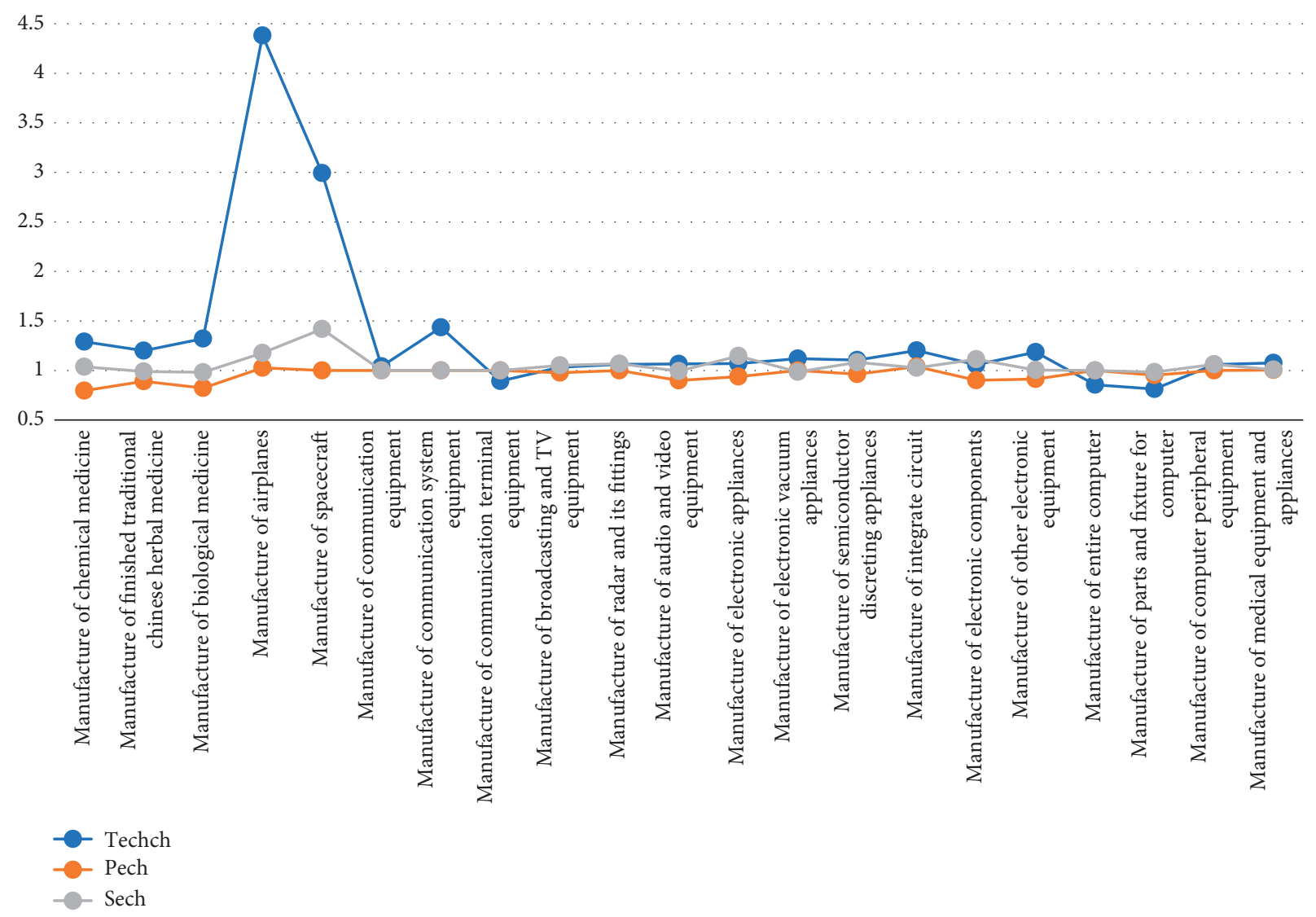

FIGURE 3: Techch, pech, and sech of high-end manufacturing industry.

their own aviation industry parks successively, introducing a number of supporting production enterprises. It can be seen that the promulgation of a series of related policies has brought excellent opportunities for the development of China's aerospace industry.

5.2.2. Time Angle. Figure 4 shows that the average total factor productivity index is 1.738 from 2012 to 2017, and the overall innovation efficiency of China's high-end manufacturing industry shows an upward trend. The annual analysis shows that the technical efficiency index (Techch) and pure technical efficiency index (Pech) in 2012-2013 and 2014-2015 are less than 1 , which indicates that the contribution of technological innovation and technological progress to the change of input efficiency in high-end manufacturing industry is weak. From 2013 to 2014, each factor of production is more than 1, which shows that the input of innovation factors in high-end manufacturing enterprises is effective; from 2015 to 2016, the efficiency of technological progress has improved slightly, but the efficiency of technology has increased by $20.05 \%$. Among them, the pure technological efficiency has increased by $18.55 \%$, and the scale efficiency has increased by $5.88 \%$. From 2016 to 2017, only the technological efficiency index (Techch) rose because in 2017, R\&D investment in China's high-tech manufacturing industry rose to a new level, with 17,163 enterprises carrying out R\&D activities, an increase of $15.7 \%$ over the previous year, accounting for more than half of all high-tech

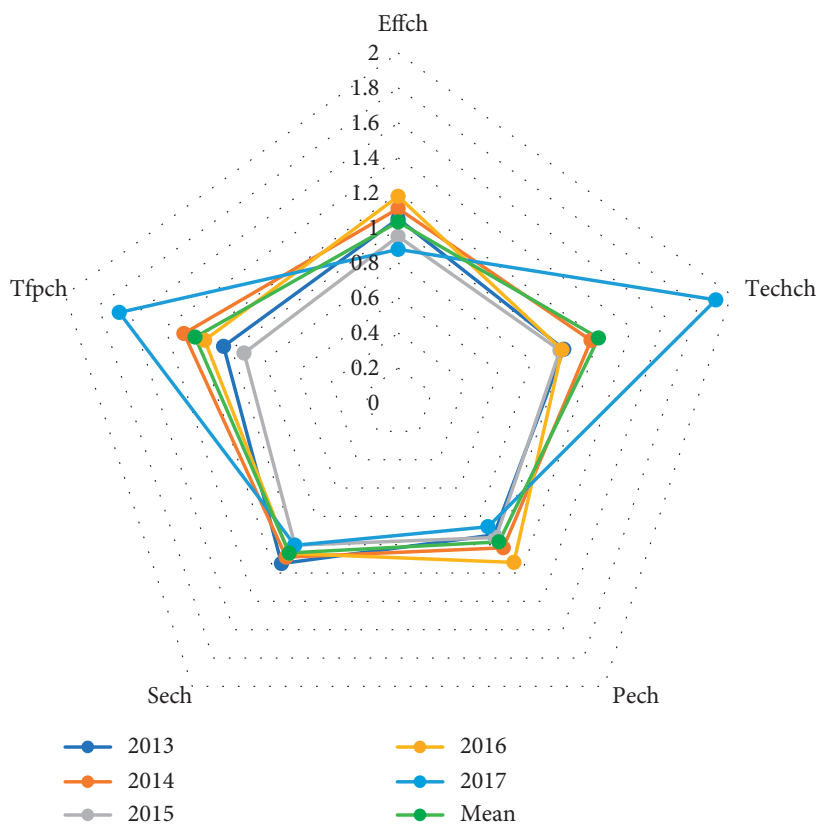

FIgURE 4: Innovation efficiency Techch, pech, and sech index of high-end manufacturing industry.

manufacturing enterprises for the first time, reaching 53.6\%. A total of 318.27 billion yuan was spent on R\&D in the high-tech manufacturing industry, an increase of $9.2 \%$ over the previous 
year. The intensity of R\&D investment (the ratio of R\&D expenditure to main business income) rose to a new level, reaching $2.0 \%$ for the first time, 1.8 times the average level of manufacturing industry.

However, compared with other countries, China's equipment manufacturing still has problems such as low innovation ability, insufficient high-end supply, and the core technology, and key parts are controlled by people. According to the research of China Machinery Industry Information Research Institute, the innovation capability index of China's equipment manufacturing industry is only $25 \%$ of that of the United States and 50\% of that of Germany. Two-third of the equipment investment in the whole society's fixed assets investment depends on imports, more than half of the technology sources of equipment manufacturing main products rely on the introduction from abroad, 70$80 \%$ of the high-end key parts of high-end equipment and high-end CNC machine tools depend on imports, and 90\% of the supporting CNC systems depend on imports.

On the surface, it is due to the insufficient development level of China's equipment manufacturing industry, the lack of large multinational companies and well-known enterprises, and the small number of leading enterprises. In essence, due to the changes in China's development stage, there is insufficient attention and support for R\&D, especially in the basic field. Although the total R\&D expenditure of China's equipment manufacturing industry has increased in recent years, the proportion is still low. For example, in 2014, China's basic research expenditure accounted for only $4.41 \%$ of its internal expenditure, far below the level of $15 \%-25 \%$ in Western developed countries. In the equipment manufacturing industry, the proportion of R\&D personnel is only $2.8 \%$, while that of developed countries is $5 \%$. China's products cannot keep up with the requirements of host development, and the basic manufacturing field has become an important factor restricting the development of China's major equipment and high-end equipment. Therefore, the technological breakthrough in the basic field is an important direction for the transformation and upgrading of the equipment manufacturing industry. In the future, we should strengthen the support for the research in the basic field in the aspects of technological breakthrough, enterprise cultivation, and talent cultivation.

From the enterprise level, out of the pursuit of short-term profits, enterprises attach great importance to the introduction of light research and development, heavy use of light research and development, and heavy imitation light innovation. Since 2004, with the increase of labour and factor costs, China's labourintensive industries have gradually lost their competitive advantages. In the future, the development of equipment manufacturing enterprises focuses on innovation ability and occupation of the middle and high-end markets. Enterprises should be encouraged to strengthen research and development, experiment in basic fields, and transfer to system integration and innovative design so as to build a competitive and influential Chinese equipment manufacturing brand.

From Figure 5, we can clearly see the trend of the total factor productivity index of China's high-end manufacturing industry from 2012 to 2017. From 2012 to 2017, the Malmquist total factor productivity index showed a fluctuating

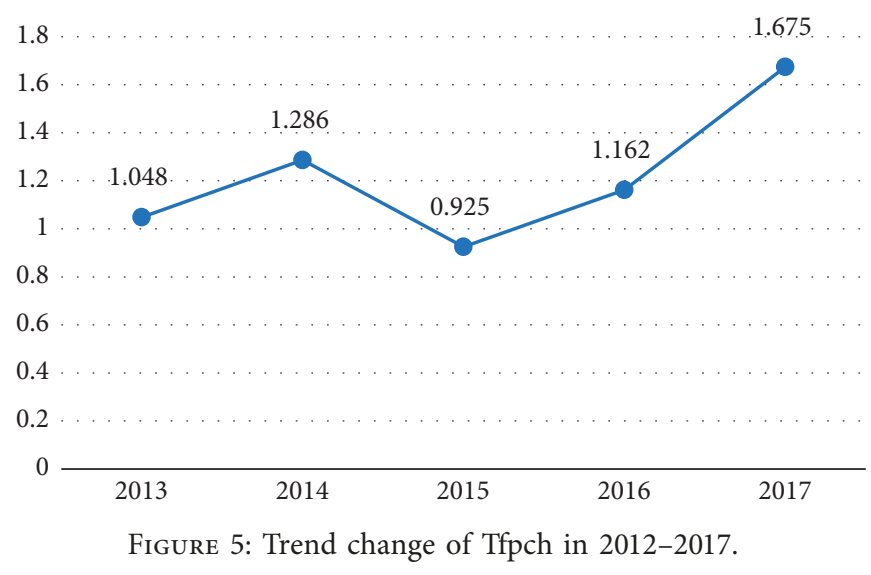

trend, which only declined in 2014-2015 (28.07\%); from 2013 to 2014 , total factor productivity increased in 2015-2016, with growth rates of $22.71 \%$ and $25.61 \%$, respectively. From 2016 to 2017 , it increased by $44.12 \%$.

The fluctuation of total factor productivity (TFP) is due to the fact that the transition from China's economy to highquality development is still in its infancy. Manufacturing industry as a whole has not yet got rid of the path dependence of scale-driven. The transformation from quantity expansion to quality improvement will be a long-term process, during which there may be fluctuations. The three indices of quality benefit, structure optimization, and sustainable development still have great room for improvement. Among them, although the gap between quality benefit is the biggest, it is also the main focus of catch-up. The future should be the main breakthrough direction of building a strong manufacturing country in China, and the quality benefit should be oriented to the manufacturing industry as a whole rather than limited to some key areas. Optimizing must be matched with quality and benefit, which is more reflected in the development of industries and links with high quality and benefit. The increase of R\&D and innovation investment in sustainable development should also be linked with industrial effect. In the future, due to uncertainties such as exchange rate fluctuations and international trade frictions, the index of China's manufacturing powers will inevitably still fluctuate, but it will not change the overall trend of the development of manufacturing powers. At present, China's manufacturing industry is accelerating the strategic transformation from quantity expansion to quality improvement. We should focus on the main line of supply side structural reform, promote the overall upgrading of manufacturing industry, speed up the construction of a modern manufacturing system with high-quality development, and lay a solid foundation for the early realization of the leap from a manufacturing power to a manufacturing power.

\section{Conclusions and Suggestion}

\subsection{Conclusion}

(1) Generally speaking, the input structure of innovation factors in China's high-end manufacturing industry 
has been gradually optimized and has entered the middle and high-end levels. However, there is a big gap in innovation efficiency among industries. The government should reduce market regulation, form a fully competitive market, and promulgate relevant supporting policies to enhance innovation efficiency; due to exchange rate fluctuations and international trade friction, the innovation efficiency should be improved. With uncertainties such as friction, there will inevitably be some fluctuations in the productivity index of China's high-end manufacturing industry, but it will not change the overall trend of the development process of manufacturing powers to be better. At the same time, we need to solve the main factor that restricts the innovation inefficiency of China's highend manufacturing enterprises as soon as possible.

Namely, the low pure technical efficiency needs to be improved as soon as possible. Therefore, it is necessary for China's high-end manufacturing industries to use the relevant theories of economics and management theory to make progress in efficiency so as to improve the level of productivity. On the contrary, the continuous introduction of relevant cutting-edge technologies can also improve the pure technical efficiency.

(2) Static data of super-SBM model show that the innovation efficiency of China's high-end manufacturing industry has an upward trend under the guidance of policies, which fully shows that the promulgation of relevant policies has promoted the development of the connotative growth mode of China's high-end manufacturing industry which depends on its own technological innovation factors and technological factors to drive economic growth. Further observation shows that the average innovation efficiency varies greatly from year to year, reaching its peak in 2016. However, the innovation efficiency of high-end manufacturing industry declined significantly in 2017, which is caused by the high cost, immature technology and the downturn of the economic situation. The process of innovation optimization of high-end manufacturing industry is not stable. It needs to further improve the policy, increase financial support, and promote the industry and coordination process.

(3) The dynamic analysis of the DEA Malmquist index shows that $22.73 \%$ of the total factor productivity of industries is effective, and the total factor productivity mainly depends on the pure technical efficiency. The technical value of manufacture of airplanes and manufacture of spacecrafts and manufacturing aircraft is significantly higher than that of other industries. This is because the national policy takes aerospace industry as the key development object and increases the support to it. As far as time is concerned, total factor productivity and its decomposition index fluctuate in different ways. They are relatively stable in the early stage and have improved significantly after
2015. However, the transition from China's economy to high-quality development is still in the initial stage, and there may be fluctuations in the future.

6.2. Policy Recommendations. At present, China is still in the golden age of high-end manufacturing industry development and innovation, and the corresponding policies need to be further optimized and improved in practice. This study evaluates and compares the innovation efficiency of 22 highend manufacturing industry segments in high-end manufacturing industry, and the conclusions can provide reference for industrial policy adjustment. In view of the above research contents and conclusions, the following policy recommendations are put forward:

\subsubsection{Level of Financial Support}

(1) Perfecting the innovation policy system and realizing the optimal allocation scale structure. We should formulate a relaxed financial support environment, increase government policies and financial support, reduce the volatility of high-end equipment manufacturing industry, and promote rapid industrial growth. The results show that the resource allocation of manufacturing innovation policy in some areas of China has not yet reached the optimal level at the high end, and there is much room for improvement. Therefore, on the one hand, the government needs to optimize the policy environment for innovation, formulate supporting measures combining incentives and feedback, and construct a perfect innovation policy system; on the other hand, it should put the policy into practice. In the process of policy making and implementation, governments should not invest resources blindly. They should fully explore the structural problems of policy matching from the perspective of technology and scale, enhance policy pertinence, and adjust policy direction appropriately. Meanwhile, governments should prevent repeated construction, reduce investment redundancy, and avoid resource waste, so as to form scale effect and drive overall economic growth.

(2) Increase financial support for industrial innovation, encourage the development of core technologies such as high-tech and high technologies, and constantly improve the quality of financing to promote industrial change. Strengthen the dominant position of enterprise innovation and enhance the ability of transformation of double-innovation achievements. Innovation subjects such as high-end manufacturing enterprises are an important part of China's overall national strength. The government should provide more policy facilities to stimulate innovation vitality. At the same time, enterprises should seize the opportunity, actively explore, and create a good internal environment. By increasing the strength of talent cultivation and improving the efficiency of capital utilization, enterprises should focus on 
solving key problems such as insufficient performance and output, gradually enhance the ability of independent innovation and achievement transformation, and give play to the effect of policy.

6.2.2. Level of Technological Innovation. Aiming at the core technologies needed in the development of high-end manufacturing industry, such as new energy technology, artificial intelligence technology, and new material manufacturing technology, we should create a professional platform for technological innovation and tackle the technical problems in the development of high-end manufacturing industry. According to the actual needs of developing highend manufacturing, bidding for high-end technology $\mathrm{R} \& \mathrm{D}$ projects is carried out, and corresponding funds and policy support are given to qualified enterprises. Relying on the favorable conditions of Shanghai's high-level education, we will effectively combine production, education, and research; encourage urban colleges and universities, scientific research institutes, and enterprise research institutes to carry out highend technology research and development; protect the achievements of independent innovation by law. Accelerate the establishment of new R\&D units and speed up the transformation of the latest technology into productivity. The distance between R\&D and market will be greatly shortened under the impetus of new R\&D institutions. Scientific and technological achievements will quickly achieve economic returns and attract more institutions to engage in technological innovation.

6.2.3. Talent Support Level. We should vigorously promote the inclusive talent apartment policy and subsidize the purchase or rental of high-level and middle-level scientific and technological talents. Enterprises and universities are encouraged to establish a joint training mechanism to cultivate a group of high-end talents who master advanced manufacturing technology and meet the needs of the current society.

Manufacturing technology meets the needs of the current society of high-end talents. Drawing lessons from the talent introduction policies of developed countries and regions, we will strive to implement the green card system for scientific and technological talents and promote the green channel for the introduction of high-end manufacturing talents in combination with the actual situation. At the same time, establish a platform for manufacturing employees to exchange experience and enrich knowledge, organize relevant competitions regularly, and speed up the cultivation of a batch of scientific and technological talents that can promote the high-end manufacturing industry.

\subsubsection{Industrial Synergy}

(1) Promote the coordinated innovation and development of industries, accelerate the interconnection of policy resources, cultivate industrial clusters, expand the industrial scale effect, and improve the output efficiency of enterprises by reducing the internal management cost. Therefore, the state should grasp the overall situation of economic development, strengthen top-level design, continue to promote industrial integration strategy, and highlight the key role of industrial synergy and innovation. Emphasis should be placed on industries with weak innovation ability, and policy support should be strengthened to minimize the unreasonable allocation of resources in different industries. At the same time, we should establish the coordination mechanism, build platform channels, encourage cross-domain cooperation among high-end manufacturing innovators, promote interindustry exchanges, guide resource interconnection, open and share experience and achievements, and create favourable conditions for collaborative innovation and collaborative development in the new economic era.

(2) It is of great significance to improve the competitiveness of high-end manufacturing industry to improve the mechanism of cross-border industrial integration. With the help of current popular technologies such as high-tech manufacturing, big data, cloud computing, and Internet, under the pressure of the development of high-end manufacturing industry and the active guidance of the government, we need to promote the development of manufacturing industry and Internet industry to explore a multiindustry cross-border integration model, and let this new model become a new direction of development of a high-end manufacturing industry and a new driving force for transformation and upgrading. At the same time, build a functional platform, rely on enterprises and industrial alliance and cross-border integration development, and seize the commanding point of manufacturing industry development. Manufacturing enterprises are encouraged to make use of new technologies and apply them to the whole process of manufacturing to promote the transformation and upgrading of all links.

\section{Data Availability}

The data used to support the findings of this study are available from the corresponding author upon request.

\section{Conflicts of Interest}

The authors declare that there are no conflicts of interest regarding the publication of this paper.

\section{References}

[1] J. H. Li, "The pattern and adjustment path of China's advanced manufacturing industry in the process of new industrial revolution," Academic Forum, vol. 41, no. 2, pp. 75-85, 2018.

[2] Y. Zhu, Z. Wang, S. Qiu, and L. Zhu, "Effects of environmental regulations on technological innovation efficiency in China's industrial enterprises: a spatial analysis," Sustainability, vol. 11, no. 7, p. 2186, 2019. 
[3] H. Y. Xin, M. Y. Wu, and P. Yao, "An analysis of the impact of reindustrialization on China's manufacturing industry," Enterprise Reform and Management, no. 22, p. 5, 2014.

[4] G. L. Shao, Q. Sun, and R. Zhang, "The strategic change of China's manufacturing industry in reindustrialization of developed countries," Fujian Lilun Xuexi, no. 10, p. 47, 2015.

[5] W. C. Yu and X. Y. Zhang, "Research on reshaping of manufacturing industry and transformation of China's manufacturing industry," Henan Social Sciences, vol. 25, no. 7, pp. 7-13+28, 2017

[6] J. H. Sun and S. Y. Wang, "Construction of financial evaluation index system for enterprise's scientific and technological innovation ability," Sub National Fiscal Research, no. 8, pp. 71-76, 2014.

[7] Q. F. Tian, S. Zhang, H. M. Yu et al., "Exploring the factors influencing business model innovation using grounded theory: the case of a Chinese high-end equipment manufacturer," Sustainability, vol. 11, no. 5, pp. 1-16, 2019.

[8] L. C. Huang, E. T. Zhang, and Z. L. Yang, "Construction and measurement of innovation index of high-end manufacturing industry based on MDM-SIM model," China Soft Science, vol. 12, pp. 144-153, 2016.

[9] Y. Li, H. Guo, and Y. T. Zhang, "Research on the way to improve technological innovation ability of high-end equipment manufacturing enterprises from the perspective of knowledge integration," Scientific Management Research, vol. 36, no. 1, pp. 34-37, 2018.

[10] X. W. Wang, "Research on innovation and competitiveness evaluation of high-end equipment manufacturing industry: a case study of Shanghai marine engineering equipment industry," Scientific Management Research, vol. 38, no. 11, pp. 36-40, 2018.

[11] P. Z. Li, L. R. Jian, and Y. Liu, "Research on innovation efficiency evaluation of regional high-tech industry based on DEA and malmquist index," Journal of Industrial Technological Economics, 2019.

[12] B. Yang and H. Cao, "Efficiency evaluation of technological innovation internationalization of universities in China based on super-efficiency SBM-malmquist model," Scientific Management Research, vol. 38, no. 16, pp. 52-56, 2018.

[13] K.-H. Park and K. Lee, "Linking the technological regime to the technological catch-up: analyzing Korea and Taiwan using the US patent data," Industrial and Corporate Change, vol. 15, no. 4, pp. 715-753, 2006.

[14] D. Libaers and M. Meyer, "Highly innovative small technology firms, industrial clusters and firm internationalization," Social Science Electronic Publishing, vol. 40, no. 10, pp. 1426-1437, 2011.

[15] X. Dai, J. Wu, and L. Yan, "A spatial evolutionary study of technological innovation talents' sticky wages and technological innovation efficiency based on the perspective of sustainable development," Sustainability, vol. 10, no. 11, p. 4201,2018 .

[16] C. G. Wang and C. S. Shi, "The influencing factors of organizational innovation of China's high-end equipment manufacturing enterprises," Scientific Management Research, vol. 37, no. 15, pp. 164-169, 2017.

[17] N. Du, D. B. Wang, and H. X. Meng, "Research on the driving factors of innovation in technological SMEs: based on WSRAHP analysis method," Economy and Management, vol. 31, no. 5, pp. 73-78, 2017.

[18] Y. W. Du, "Research on the influencing factors of productive services promoting manufacturing industry upgrading in China: an empirical analysis based on super-efficiency DEA and tobit model," Commercial Research, no. 6, pp. 145-153, 2017.

[19] K. Tone, "A slacks-based measure of efficiency in data envelopment analysis," European Journal of Operational Research, vol. 130, pp. 498-509, 2001.

[20] K. Tone, "A slacks-based measure of super-efficiency in data envelopment analysis," European Journal of Operational Research, vol. 143, no. 1, pp. 32-41, 2002.

[21] R. Fare, S. Grosskopf, M. Norris et al., "Productivity growth, technical progress and efficiency change in industrialized countries," American Economic Review, vol. 84, pp. 66-83, 1994.

[22] R. Fare, S. Grosskopf, M. Norris et al., "Productivity growth, technical progress and efficiency change in industrialized countries: reply," American Economic Review, vol. 87, pp. 1040-1043, 1997. 


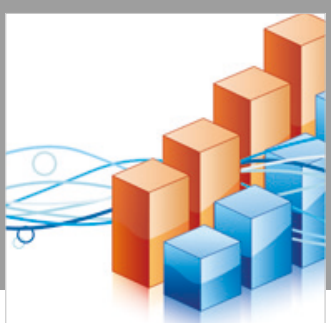

Advances in

Operations Research

\section{-n-m}
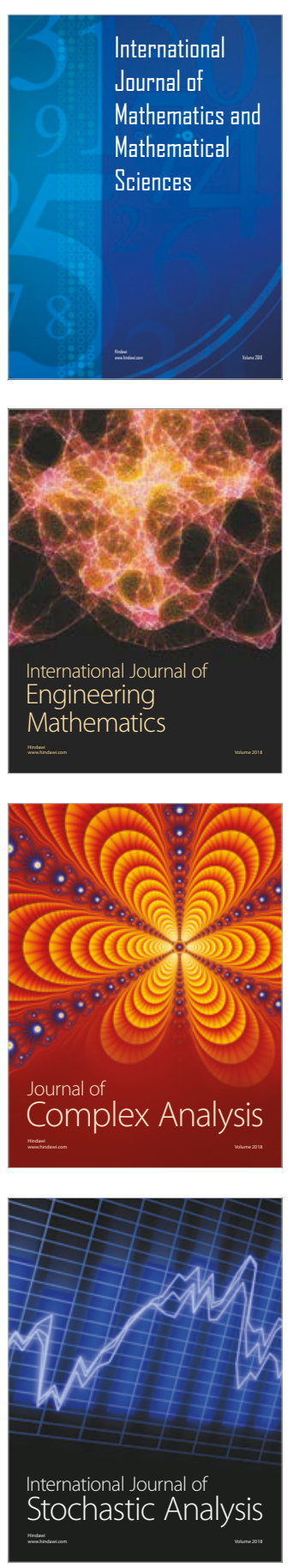
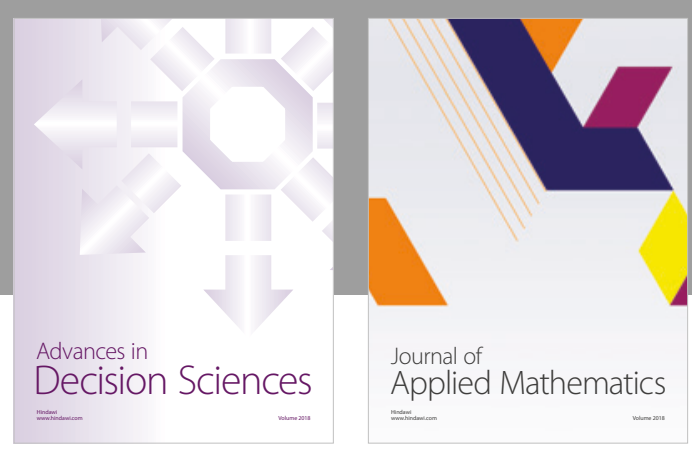

Journal of

Applied Mathematics
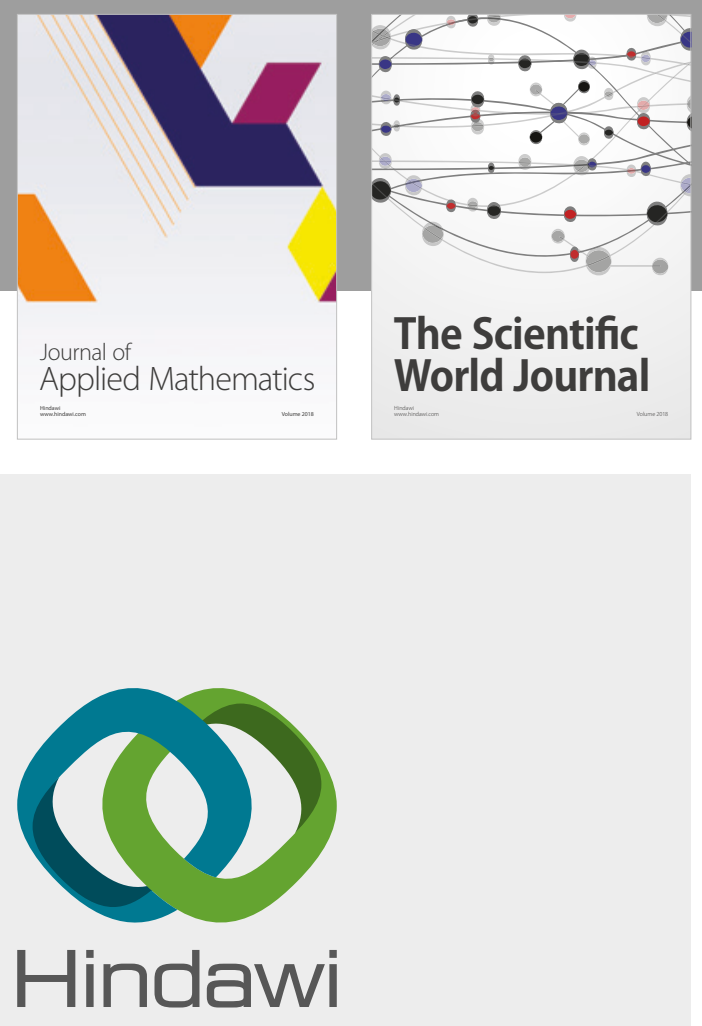

Submit your manuscripts at

www.hindawi.com

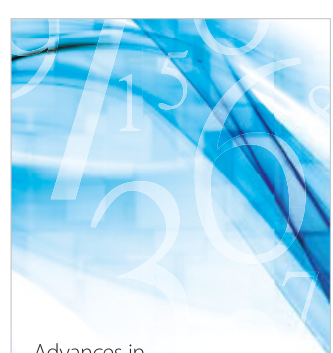

Advances in
Numerical Analysis
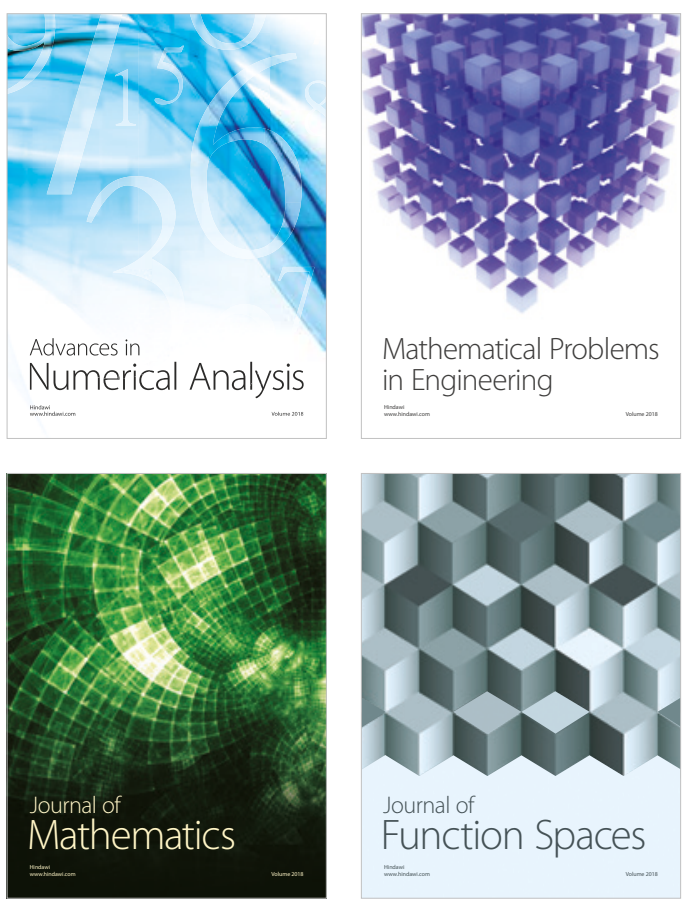

Mathematical Problems in Engineering

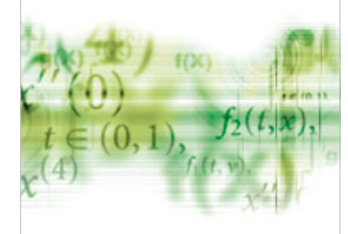

International Journal of

Differential Equations

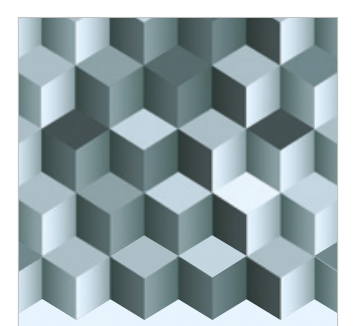

Journal of

Function Spaces

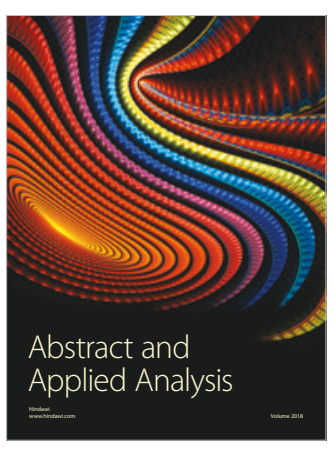

The Scientific

World Journal

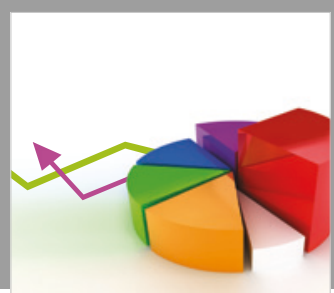

Journal of

Probability and Statistics
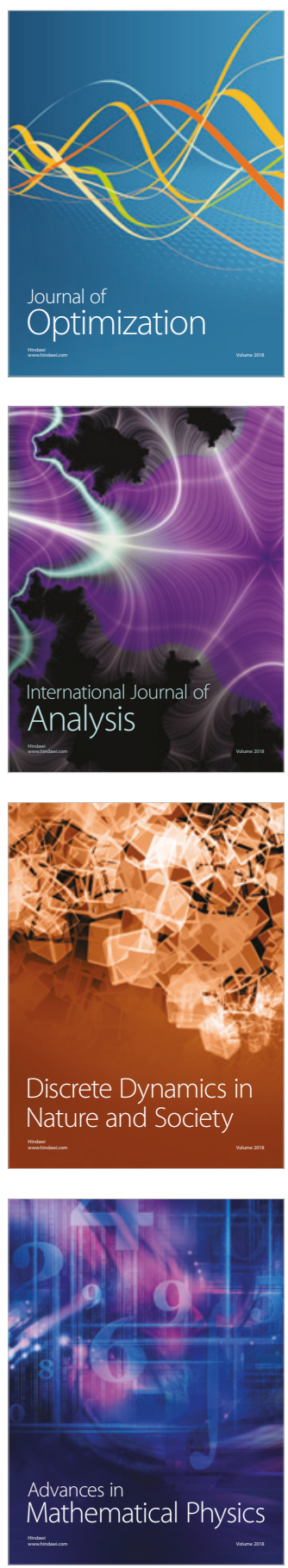